\title{
New health minister promises open door, pledges to work with doctors
}

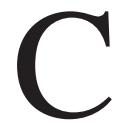
anada's new Health Minister Rona Ambrose attempted to mend her predecessor's sometimes strained relationship with the country's leading doctors in an Aug. 19 speech to the Canadian Medical Association. In particular, she promised to listen to and work with physicians, and to have an open-door policy for their representatives to discuss the nation's pressing health issues, particularly family violence.

"As the new minister of health, I come to the job with an open mind and with a spirit of collaboration," Ambrose told more than 300 doctors and other health care professionals at the Canadian Medical Association (CMA) 146th annual general meeting in Calgary, Alberta.

In contrast to former health minister Leona Aglukkaq, Ambrose promised to spend the entire day at the conference, attending education sessions and meeting with the CMA's executive committee, and also talk to delegates to get "perspectives from the front line."

"I want to hear from you one-on-one," she said. "As a new minister, I think listening is better than telling you what I know about the health care system."

Ambrose's tone was conciliatory, and she sprinkled her speech with references to partnerships and the importance of the CMA's advocacy for better health care on behalf of Canadians, and praised doctors for their leadership on issues ranging from mental health care to improving the social determinants of health.

In recent months, the CMA and other leading health care organizations have complained that they received no response to letters or requests for meetings from Aglukkaq on issues of concern, particularly the federal government's stance on refugee health care. Significantly, Ambrose avoided any mention of Ottawa's cuts to health coverage for refugees a year ago.

The new health minister emphasized her former role as minister for the sta-

tus of women in strengthening family violence prevention initiatives, an issue she promised to continue to champion.

"Family violence is a health issue," Ambrose told the doctors. "Last year a report from Justice Canada found

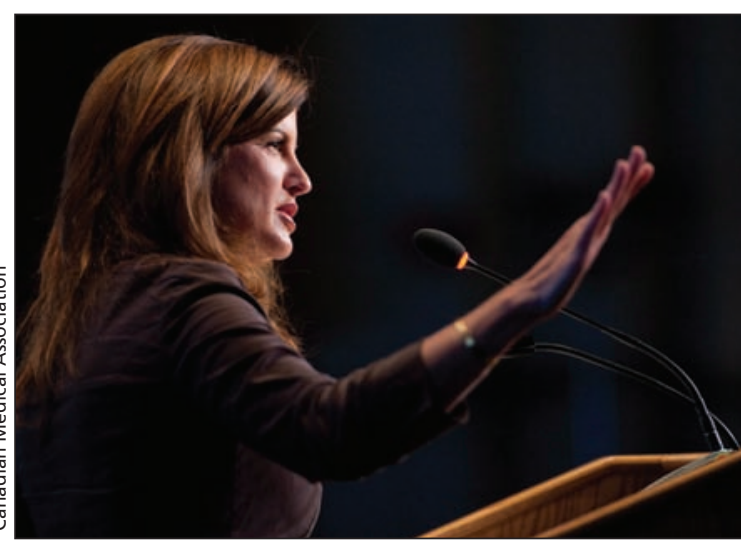

Health Minister Rona Ambrose says she has come to her new job "with an open mind and with a spirit of collaboration."

spousal violence alone cost society at least $\$ 7.4$ billion annually. Of that total, an estimated $\$ 6$ billion accounts for health care costs for medical treatment and psychological services."

In 2012 in Calgary alone, Ambrose said police investigated 329 cases of severe sexual and physical abuse of children under 17.

"Aboriginal women are three-anda-half times more likely than nonAboriginal women to be victims of violence," she added. She urged doctors to recognize the signs of family violence, report it and ensure their patients get the treatment and support they need.

Ambrose has asked the Public Health Agency of Canada to identify opportunities within its budget that could help end family violence.

The minister also pledged to improve health care for First Nations and Inuit Canadians, citing British Columbia's Tripartite First Nations Health Plan as a model she hopes the rest of Canada can learn from. It involves Aboriginal Canadians in the design and delivery of health care that is integrated within the provincial health care system.

Ambrose quickly reiterated her government's commitment to a strong, publicly funded medicare system "guided by the Canada Health Act," although she stressed the need to improve productivity and find more efficiencies - phrases often aligned with the pressure to allow more privatization of services.

"I believe we are at a critical point where we must improve the productivity of the health system and improve the health of Canadians together," she said.

Ambrose also stressed the federal government's role in funding research and innovation, an area in health care policy that Prime Minister Stephen Harper and his cabinet colleagues have championed. Ambrose's speech signalled that research and development funding will be targeted, however, in a particular direction: how technology can drive productivity in the health system and provide incentives for more cost-effective health care interventions.

"This is the policy challenge that I believe is worthy of federal leadership and an area I believe we can make gains (in) together."

Ambrose's speech did not include any funding announcements and steered clear of setting new policy directions. Instead, she peppered it with personal references to her own style - such as being a selfdescribed "policy wonk" who plans to dive into the critical issues, and her personal commitment to staying healthy, as evidenced by her recent vacation backpacking $70 \mathrm{~km}$ in the Rocky Mountains.

The speech was a clear exercise in relationship building — a shift in direction sure to appeal to the health care leaders who had previously felt their advocacy unappreciated by this government. - Laura Eggertson, CMAJ

CMAJ 2013. DOI:10.1503/cmaj.109-4584 